\title{
Erratum to: FTIR spectroscopy of Ti-chondrodite, Ti-clinohumite, and olivine in deeply subducted serpentinites and implications for the deep water cycle
}

Tingting Shen · Jốrg Hermann · Lifei Zhang •

José Alberto Padrón-Navarta $\cdot$ Jing Chen

Published online: 22 July 2014

(C) Springer-Verlag Berlin Heidelberg 2014

Erratum to: Contrib Mineral Petrol (2014) 167:992

DOI 10.1007/s00410-014-0992-8

In the original publication, the IR bands of Ti-chondrodite and Ti-clinohumite are published with an incorrect value " 3,583-3,586 $\mathrm{cm}^{-1}$ " in the occurrences of abstract and conclusion sections. The correct IR band levels should be " 3,383-3,386 cm $\mathrm{cm}^{-1}$.

The online version of the original article can be found under doi:10.1007/s00410-014-0992-8.

T. Shen $(\varangle) \cdot$ J. Hermann $\cdot$ J. A. Padrón-Navarta

Research School of Earth Sciences, The Australian National

University, Canberra, ACT 0200, Australia

e-mail: shentt@pku.edu.cn

T. Shen $\cdot$ L. Zhang $\cdot$ J. Chen

Key Laboratory of Orogenic Belts and Crustal Evolution,

MOE, School of Earth and Space Sciences, Peking University,

Beijing 100871, China

J. A. Padrón-Navarta

Géosciences Montpellier, CNRS, Univ. Montpellier 2,

34095 Montpellier, France 